\title{
ANALISIS TINGKAT KEPATUHAN PENGGUNAAN OBAT TUBERKULOSIS MENGGUNAKAN MEDICATION ADHERENCE RATING SCALE (MARS)
}

\author{
Lisus Setyowati ${ }^{1)}$, Ernest Silviah Emil ${ }^{2)}$ \\ ${ }_{1,2}$ Prodi DIII Farmasi, Sekolah Tinggi Ilmu Kesehatan Harapan Bangsa, Jember, Indonesia \\ email: lisussetyowati89@gmail.com
}

\begin{abstract}
Abstrak
Penyakit TB (Tuberculosis) paru merupakan penyakit yang mudah menular yang disebabkan oleh Mycobacterium Tuberculosis dan penularannya melalui udara dalam bentuk percikan dahak (droplet). Keberhasilan program TB di Indonesia dapat dicapai dengan program pemerintah yaitu strategi Directly Observed Treatment, short-course (DOTS). Penelitian ini untuk mengetahui tingkat kepatuhan pengobatan $T B$ di RS Paru Kabupaten Jember dan untuk mengetahui hubungan antara karakteristik responden dengan tingkat kepatuhan pengobatan TB. Penelitian ini merupakan penelitian deskriptif kuantitatif dengan pendekatan cross sectional dilakukan dengan wawancara. Variabel yang diteliti adalah karakteristik (jenis kelamin, usia, dan tingkat pendidikan) dan kepatuhan pengobatan pasien TB. Penilaian kepatuhan pasien dilakukan menggunakan kuesioner MARS untuk mengetahui hasil penelitian tingkat kepatuhan pengobatan pasien TB. Data dianalisis menggunakan uji univariat dan uji chi square dengan taraf signifikasi ( $\alpha$ ) $5 \%$. Tingkat kepatuhan pengobatan sebesar 77,5\%. Jenis kelamin Laki-laki 62,5\% (p=0,769), usia 35-44 tahun $40 \%$ ( $p=0,567)$, dan tingkat pendidikan SD 42,5\% ( $p=0,953)$ tidak berhubungan dengan kepatuhan pengobatan TB di RS Paru Kabupaten Jember. Perlu dukungan keluarga atau Pengawas Minum Obat (PMO) untuk keberhasilan program DOTS dan melakukan penelitian lebih lanjut untuk perilaku hidup pasien dan motivasi pasien untuh sembuh dari TB.
\end{abstract}

Kata kunci: kepatuhan, karakteristik, tuberkulosis paru

\begin{abstract}
Pulmonary TB (Tuberculosa) is an infectious disease caused by Mycobacterium Tuberculosis and is transmitted through the air in the form of droplets. The success of the TB program in Indonesia can be achieved by a government program, Directly Observed Treatment, short-course (DOTS) strategy. This study was to determine the level of compliance with TB treatment and for the relationship between the characteristics of the respondents and the level of compliance with TB treatment at Lung Hospital, Jember. This research is a descriptive quantitative study with a cross sectional approach. Compliance assessment of patient was assessed by using the MARS questionnaire to determine the level of compliance to treatment of $T B$ patients. Data were analyzed using univariate test and chi square test with a significance level $(\alpha)$ of $5 \%$. Treatment adherence rate was 77.5\%. Male gender $62.5 \%(p=0.769)$, age 35-44 years 40\% $(p=0.567)$, and SD education level $42.5 \%(p=0.953)$ did not correlate with TB treatment compliance at Lung Hospital Jember. It is necessary to have family support or Drug Administration (PMO) for the success of the DOTS program and to carry out further research on patient behavior and motivation for patients to recover from $T B$.
\end{abstract}

Keywords: compliance, characteristics, pulmonary tuberculosis

\section{PENDAHULUAN}

Penyakit tuberkulosis (TB) merupakan penyakit mudah menular yang masih menjadi masalah kesehatan utama di dunia. Indonesia termasuk dengan pasien TB terbanyak ketiga di dunia setelah India dan Cina. Berdasarkan data organisasi kesehatan dunia World Health
Organization (WHO), kasus TB di Indonesia mencapai 842 ribu. Sebanyak 442 ribu terdiagnosis dan sekitar 400 ribu lainnya tidak terdiagnosis. Penderita TB tersebut terdiri atas 492 ribu laki-laki, 349 ribu perempuan, dan 49 ribu anak-anak (Kusnandar, 2018). 
Provinsi Jawa Timur menempati peringkat kedua di Indonesia dengan kasus TB mencapai angka 57.442 kasus pada tahun 2018. Berdasarkan data Dinas Kesehatan Jember, jumlah penderita TB setiap tahunnya mengalami peningkatan, yaitu sebanyak 3497 kasus pada tahun 2017. Tingginya kasus TB disebabkan rendahnya pencegahan yang dilakukan masyarakat, gaya hidup dan lingkungan yang tidak sehat, serta ventilasi udara dan cahaya matahari kedalam rumah atau rumah dalam kondisi lembab serta sanitasi yang kurang baik sehingga TB mudah berkembang. Disamping itu, masih tingginya angka penderita TB juga dipengaruhi oleh kepatuhan pasien selama dalam masa pengobatan. Indonesia menerapkan strategi Directly Observed Treatment, short-course (DOTS) yang bertujuan untuk meningkatkan kepatuhan dan menuntaskan pengobatan (Aditama \& Subuh, 2011).

DOTS menempatkan pasien di pusat pengendalian TB dan memastikan kerahasiaan pasien, mengatur layanan TB sehingga pasien memiliki perawatan sedekat mungkin dengan rumah, menjaga keakuratan alamat, dan mengambil tindakan untuk pasien yang tidak mau berobat (Anengsih, 2017). Faktor-faktor yang dapat mempengaruhi kepatuhan pengobatan antara lain, jenis kelamin, usia, pencapaian pendidikan, status perkawinan, depresi, kurangnya kepatuhan pasien TB untuk berobat dan minum obat, merokok, masalah ekonomi dan lamanya perawatan yang akan dijalani (Danso et al., 2015). Selain itu, pemberdayaan keluarga penderita TB paru berpengaruh terhadap kemampuan melaksanakan tugas kesehatan keluarga dalam pencegahan, perawatan dan pengobatan TB paru. Berbagai faktor penyebab ketidakpatuhan pengobatan minum obat penderita TB paru dapat disimpulkan bahwa faktor manusia (baik penderita maupun PMO) sebagai penyebab utama. Faktor manusia yang dimaksud adalah bagaimana perilaku individu tersebut, diantaranya karakteristik individu, pengetahuan dan penilaian terhadap sikap pelayanan kesehatan (Marwansyah \& Sholikhah, 2015).

Berdasarkan uraian tersebut diatas, maka peneliti merasa perlu melakukan penelitian dengan menggunakan kuesioner Medication Adherence Rating Scale (MARS) yang dikembangkan oleh (Thompson et al., 2000) karena dianggap lebih praktis, murah dan efisien sehingga di harapkan dapat memperbaiki hasil tujuan terapi dan meningkatkan keberhasilan pengobatan pasien TB dengan cara memberikan konseling kepada pasien agar patuh berobat di Rumah Sakit Paru Kabupaten Jember. Penelitian ini dilaksankan untuk mengetahui tingkat kepatuhan pasien terhadap pengobatan TB di Rumah Sakit Paru Kabupaten Jember.

\section{METODE PENELITIAN}

Penelitian ini menggunakan jenis penelitian deskriptif kuantitatif, yaitu untuk mendeskripsikan atau menggambarkan kepatuhan pasien dalam penggunaan obat TB di Rumah Sakit Paru Kabupaten Jember. Metode yang digunakan dalam penelitian ini adalah survei, melalui wawancara dengan menggunakan kuesioner dengan pendekatan cross sectional.

Populasi dalam penelitian ini adalah seluruh pasien TB yang menjalani fase lanjutan di Rumah Sakit Paru selama bulan Juli 2020 dan yang digunakan sebagai sampel adalah pasien yang bersedia menjadi responden dan memenuhi kriteria responden sejumlah 40 yang didapatkan dengan teknik total sampling. Teknik pengumpulan data dalam penelitian ini didapatkan dari hasil wawancara menggunakan kuesioner MARS untuk menilai kepatuhan pengobatan TB. Setelah semua data terkumpul, maka akan dianalisis dengan melakukan analisis deskriptif (univariat) dan bivariate untuk mengetahui hubungan antara karakteristik pasien (jenis kelamin, usia, dan tingkat pendidikan) dengan tingkat kepatuhan. Uji statistik yang digunakan adalah Chi Square untuk menguji hipotesis dalam populasi yang terdiri atas dua atau lebih kelas dimana datanya berbentuk kategorik.

\section{HASIL DAN PEMBAHASAN}

\section{a. Karakteristik Responden}

Tabel 1. Distribusi Frekuensi Pasien TB Berdasarkan Karakteristik Responden

\begin{tabular}{|c|c|c|}
\hline $\begin{array}{c}\text { Karakteristik } \\
\text { Responden }\end{array}$ & Jumlah & $\begin{array}{c}\text { Persentase } \\
(\%)\end{array}$ \\
\hline \multicolumn{3}{|l|}{ Jenis Kelamin } \\
\hline Laki-laki & 25 & 62,50 \\
\hline Perempuan & 15 & 37,50 \\
\hline \multicolumn{3}{|c|}{ Usia Responden (Tahun) } \\
\hline $15-24$ & 6 & 15,00 \\
\hline $25-34$ & 7 & 17,50 \\
\hline $35-44$ & 16 & 40,00 \\
\hline $45-54$ & 11 & 27,50 \\
\hline \multicolumn{3}{|l|}{ Tingkat Pendidikan } \\
\hline SD & 17 & 42,50 \\
\hline SLTP & 7 & 17,50 \\
\hline SLTA & 12 & 30,00 \\
\hline Akademi / Sarjana & 4 & 10,00 \\
\hline Total & 40 & 100,00 \\
\hline
\end{tabular}

Berdasarkan tabel 1 distribusi frekuensi responden dapat diambil kesimpulan bahwa dari 40 responden pasien TB Paru yang mengikuti pengobatan sistem DOTS di RS Paru didominasi oleh laki-laki dengan jumlah 25 orang $(62,50 \%)$, sedangkan 
perempuan sebanyak 15 orang $(37,50 \%)$. Dilihat dari segi usia yaitu usia 15-24 tahun sebanyak 6 orang $(15,00 \%)$, usia $25-34$ tahun sebanyak 7 orang $(17,5 \%)$, usia 35-44 tahun sebanyak 16 orang $(40,00 \%)$, dan usia 45-54 tahun sebanyak 11 orang (27,5\%). Dilihat dari tingkat pendidikan yaitu responden dengan tingkat pendidikan SD sebanyak 17 orang (42,5\%); SLTP sebanyak 7 orang (17,5\%); SLTA sebanyak 12 orang (30\%); dan tingkat pendidikan Akademi/ Sarjana sebanyak 4 orang $(10 \%)$.

Tabel 2. Distribusi Frekuensi Pasien TB Berdasarkan Tingkat Kepatuhan

\begin{tabular}{lcc}
\hline Kepatuhan & $\begin{array}{c}\text { Jumlah } \\
\text { Responden }\end{array}$ & $\begin{array}{c}\text { Persentase } \\
(\boldsymbol{\%})\end{array}$ \\
\hline Patuh & 31 & 77,5 \\
Tidak Patuh & 9 & 22,5 \\
\hline \multicolumn{1}{c}{ Total } & 40 & 100,0 \\
\hline
\end{tabular}

Berdasarkan tabel 2 dapat dijelaskan bahwa tingkat kepatuhan dalam pengobatan TB di RS Paru Kabupaten Jember sebesar 77,5\% yang berarti tingkat kepatuhan pasien dalam berobat cukup tinggi.

\section{b. Hubungan Karakteristik Responden (Jenis kelamin, usia, dan tingkat pendidikan) Dengan Kepatuhan}

Tabel 3. Hubungan Jenis Kelamin dengan Kepatuhan Pengobatan

\begin{tabular}{|c|c|c|c|c|}
\hline $\begin{array}{l}\text { Jenis } \\
\text { Kelamin }\end{array}$ & $\begin{array}{c}\text { Patuh } \\
(\%)\end{array}$ & $\begin{array}{c}\text { Tidak } \\
\text { Patuh } \\
(\%)\end{array}$ & $\begin{array}{c}\text { Jumlah } \\
(\%)\end{array}$ & $\begin{array}{c}p \\
\text { value }\end{array}$ \\
\hline Laki-laki & $\begin{array}{l}0,47 \\
(19)\end{array}$ & $\begin{array}{l}0,15 \\
(6)\end{array}$ & $\begin{array}{l}0,62 \\
(25)\end{array}$ & \multirow{3}{*}{0,769} \\
\hline Perempuan & $\begin{array}{c}0,3 \\
(12)\end{array}$ & $\begin{array}{c}0,08 \\
(3)\end{array}$ & $\begin{array}{l}0,38 \\
(15)\end{array}$ & \\
\hline Total & $\begin{array}{l}0,77 \\
(31)\end{array}$ & $\begin{array}{c}0,23 \\
(9)\end{array}$ & $\begin{array}{l}100 \\
(40)\end{array}$ & \\
\hline
\end{tabular}

Berdasarkan tabel 3, dijelaskan bahwa berkaitan dengan jenis kelamin pada pengobatan TB di RS Paru Kabupaten Jember didominasi oleh jenis kelamin laki-laki sebesar 25 orang yang berarti pasien TB berjenis kelamin laki-laki lebih banyak dibanding dengan pasien yang berjenis kelamin perempuan yaitu sebesar 15 orang. Nilai uji Chi Square 0,769 yang berarti tidak ada hubungan antara jenis kelamin dan kepatuhan pengobatan.

Penelitian ini tidak sama dengan penelitian (Primadiah, 2012) yang menyatakan bahwa jenis kelamin berhubungan dengan kepatuhan pengobatan TB. Hal ini dikarenakan setiap individu dengan jenis kelamin laki-laki dan perempuan tidak terlalu mempengaruhi keputusan responden untuk patuh dalam meminum obat TB (Yuda, 2018).

\section{c. Hubungan usia dengan tingkat kepatuhan pengobatan pasien TB di RS Paru dapat dilihat pada tabel berikut:}

Tabel 4. Hubungan Usia dengan Kepatuhan Pengobatan

\begin{tabular}{ccccc}
\hline Usia & Patuh & $\begin{array}{c}\text { Tidak } \\
\text { Patuh }\end{array}$ & Jumlah & $\begin{array}{c}\boldsymbol{p} \\
\text { value }\end{array}$ \\
\hline $15-24$ & 5 & 1 & 6 & \\
$25-34$ & 4 & 3 & 7 & \\
$35-44$ & 13 & 3 & 16 & 0,567 \\
$45-54$ & 9 & 2 & 11 & \\
\hline Total & $0,82 \%$ & $0,18 \%$ & $100 \%$ & \\
& 33 & 7 & 40 & \\
\hline
\end{tabular}

Berdasarkan tabel 4, dijelaskan bahwa berkaitan dengan usia pada pengobatan TB di RS Paru Kabupaten Jember didominasi pada pasien dengan usia 35-44 tahun sebanyak 16 orang dengan nilai Chi Square 0,567 yang berarti tidak ada hubungan antara usia dengan kepatuhan pengobatan.

Penelitian ini tidak sama dengan penelitian (Primadiah, 2012) yang menyatakan bahwa usia berhubungan dengan kepatuhan pengobatan TB. Hal ini dikarenakan semua pasien TB Paru ingin sembuh dari penyakitnya sehingga patuh untuk mengikuti paduan obat yang diberikan walaupun memakan waktu yang lama (Kondoy et al., 2014).

\section{d. Hubungan tingkat pendidikan dengan tingkat kepatuhan pengobatan pasien TB di RS Paru}

Tabel 5. Hubungan Tingkat Pendidikan dengan Kepatuhan Pengobatan

\begin{tabular}{|c|c|c|c|c|}
\hline $\begin{array}{c}\text { Tingkat } \\
\text { Pendidikan }\end{array}$ & $\begin{array}{c}\text { Patuh } \\
(\%)\end{array}$ & $\begin{array}{c}\text { Tidak } \\
\text { Patuh } \\
(\%)\end{array}$ & $\begin{array}{c}\text { Jumlah } \\
(\%)\end{array}$ & $p$ value \\
\hline \multirow{2}{*}{ SD } & 0,33 & 0,1 & 0,43 & \multirow{10}{*}{0,953} \\
\hline & (13) & (4) & (17) & \\
\hline \multirow{2}{*}{ SLTP } & 0,15 & 0,03 & 0,18 & \\
\hline & (6) & (1) & (7) & \\
\hline \multirow{2}{*}{ SLTA } & 0,225 & 0,05 & 0,3 & \\
\hline & (9) & (2) & (12) & \\
\hline \multirow{2}{*}{$\begin{array}{l}\text { Akademi / } \\
\text { Sarjana }\end{array}$} & 0,08 & 0,02 & 0,1 & \\
\hline & (3) & (1) & (4) & \\
\hline \multirow{2}{*}{ Total } & 0,8 & 0,2 & 100 & \\
\hline & (33) & (7) & (40) & \\
\hline
\end{tabular}


Hasil penelitian pada tabel 5 menunjukkan bahwa responden yang patuh 13 orang dengan tingkat pendidikan SD, 6 orang dengan tingkat pendidikan SLTP, 9 orang dengan tingkat pendidikan SLTA, dan 3 orang dengan tingkat pendidikan Akademi/ Sarjana. Responden yang tidak patuh 4 orang dengan tingkat pendidikan SD, 1 orang dengan tingkat pendidikan SLTP, 3 orang dengan tingkat pendidikan SLTA, dan 1 orang dengan tingkat pendidikan Akademi/ Sarjana. Hasil uji statistik Chi Square diperoleh nilai $p$ sebesar $0,953(p>\alpha)$ yang berarti tidak ada hubungan antara tingkat pendidikan penderita TB dengan kepatuhan pengobatan TB di RS Paru Kabupaten Jember.

Penelitian ini tidak sama dengan penelitian (Kondoy et al., 2014) yang menyatakan bahwa pendidikan memiliki hubungan yang bermakna dengan tingkat kepatuhan berobat pasien TB Paru. Tindakan pendidikan formal merupakan landasan seseorang dalam berbuat sesuatu, membuat lebih mengerti, dan memahami sesuatu.Hal ini dapat terjadi karena pola pengobatan tuberculosis yang memang memiliki aturan tersendiri tentang jenis obatnya yang lebih dari satu dan lama pengobatannya minimal 6 bulan. Aturan ini membuat penderita merasa bosan atau terbebani dan di tengah pengobatan merasa sudah sembuh sehingga menghentikan minum obat ditengah waktu (drop out). Kondisi ini sangat mengkhawatirkan karena dapat memicu timbulnya kuman resisten yang mengancam kesehatan secara global (Suswati, 2006).

Kepatuhan sangat berpengaruh terhadap pengobatan TB karena pasien yang mengacu pada prosedur terapi TB dan menjalankan semua instruksi yang diberikan oleh petugas medis akan memberikan hasil terapi yang baik. Selain kepatuhan dalam berobat ke RS Paru, pasien juga harus tepat dalam mengkonsumsi obatnya baik dosis obat yang diminum dan waktu pemberian obat, Obat dapat mempengaruhi farmakokinetik, sehingga dapat menimbulkan hilangnya efikasi atau timbulnya resistensi obat. Penggunaaan dosis rendah dapat menyebabkan konsentrasi obat puncak lebih rendah dari biasanya dan total lebih rendah pajanan obat, sedangkan dosis ekstra dapat mengakibatkan risiko toksisitas karena lebih tinggi dari biasanya konsentrasi puncak dan eksposur total (Vernon et al., 2019).

Kepatuhan responden dalam hal pengobatan bukanlah satu-satunya faktor penentu keberhasilan. Faktor pendukung lain untuk meningkatkan keberhasilan terapi pengobatan yaitu pola hidup pasien yang baik dengan berperilaku bersih dan sehat, tidur dan istirahat yang cukup, tidak merokok dan minum alkohol, melengkapi kebutuhan gizi pasien, imunisasi BCG pada bayi, dan menjaga daya tahan tubuh (imunitas) pasien karena bila daya tahan tubuh lemah mudah untuk bakteri masuk dalam tubuh. Perilaku sehat seperti meludah jangan sembarangan, batuk sebaiknya di tutupi tisu atau sapu tangan, menggunakan masker, kedekatan dengan keluarga dibatasi, gizi sebaiknya seimbang.

\section{KESIMPULAN DAN SARAN}

Dari penelitian yang telah dilakukan, dapat disimpulkan bahwa tingkat kepatuhan dalam pengobatan TB di RS Paru Kabupaten Jember sebesar $77,5 \%$. Karakteristik penderita TB Paru di RS Paru Kabupaten Jember didimonasi oleh penderita berjenis kelamin laki-laki sebesar $62,5 \%$, sebagian besar berusia produktif yaitu usia 35-44 tahun dengan prosentase sebesar $40 \%$, dan tingkat pendidikan SD sebesar $42,5 \%$. Tidak terdapat hubungan antara karakteristik responden (jenis kelamin, usia, dan tingkat pendidikan) dengan kepatuhan pengobatan TB Paru di RS Paru Kabupaten Jember.

Untuk penelitian selanjutnya, diharapkan dapat melakukan penelitian mulai dari pengobatan di fase awal atau intensif. Disamping itu, penelitian selanjutnya juga perlu dikaitkan dengan pola hidup pasien, motivasi pasien, dan outcome yang diharapkan.

\section{REFERENSI}

Aditama, T. Y., \& Subuh, M. (2011). Strategi Nasional Pengendalian TB di Indonesia 2010-2014. Jakarta: Kementerian kesehatan Republik Indonesia. https://med.unhas.ac.id/farmakologi/ wpcontent/uploads/2014/10/PedomanNasional-Penanggulangn-TB-2011.pdf

Anengsih, C. P. (2017). Implementasi Penanggulangan TB Paru dengan Strategi DOTS (Directly Observed Treatment Shortcourse) di Wilayah Kerja Puskesmas Batupanga Kabupaten Polewali Mandar. Makasar: Jurusan Kesehatan Masyarakat UIN Alauddin Makasar.

Danso, E., Addo, I. Y., \& Ampomah, I. G. (2015). Patients , Compliance with Tuberculosis Medication in Ghana: Evidence from a Periurban Community. 2015. 
Kondoy, P. P. H., Rombot, D. V., Palandeng, H. M. F., \& Pakasi, T. A. (2014). Faktor-Faktor Yang Berhubungan Dengan Kepatuhan Tuberkulosis Paru di Lima Puskesmas di Kota Manado Berobat Pasien. Jurnal Kedokteran Dan Komunitas Dan Tropik, II (1), 1-8.

Kusnandar, V. B. (2018). WHO: Kasus TBC Indonesia 2017 Terbesar Ketiga Dunia. https://databoks.katadata.co.id/datapublish/20 19/10/09/who-kasus-tbc-indonesia-2017terbesar-ketiga-dunia

Marwansyah, \& Sholikhah, H. H. (2015). Pengaruh Pemberdayaan Keluarga Penderita TB ( Tubercolosis) Paru Terhadap Kemampuan Melaksanakan Tugas Kesehatan Keluarga di Wilayah Puskesmas Martapura dan Astambul Kabupaten Banjar. Buletin Penelitian Sistem Kesehatan, 18(4), 407-419.

Primadiah, N. (2012). Hubungan Karakteristik Demografi dengan Kepatuhan Berobat Pasien TB Paru di RS Paru Jember. Jember: Fakultas Kedokteran Universitas Jember.
Suswati, E. (2006). Hubungan tingkat pendidikan dengan kepatuhan minum obat pada penderita tuberkulosis paru. Pengembangan Pendidikan, 3(1), 67-73.

Thompson, K., Kulkarni, J., \& Sergejew, A. A. (2000). Reliability and validity of a new Medication Adherence Rating Scale ( MARS) for the psychoses Reliability and validity of a new Medication Adherence Rating Scale (MARS) for the psychoses $k$. 42, 241-247. https://doi.org/10.1016/S0920-964(99)00130-9

Vernon, A., Fielding, K., Savic, R., Dodd, L., \& Nahid, P. (2019). The importance of adherence in tuberculosis treatment clinical trials and its relevance in explanatory and pragmatic trials. PLOS Medicine, 1-10. https://doi.org/10.1371/journal.pmed.1002884

Yuda, A. A. (2018). Hubungan Karakteristik, Pengetahuan, Sikap dan Tindakan Penderita Tuberkulosis Paru dengan Kepatuhan Minum Obat di Puskesmas Tanah Kalikedinding. Surabaya: Program Studi Pendidikan Ners Universitas Airlangga. 